\title{
Front Matter: Volume 10664
}

, "Front Matter: Volume 10664," Proc. SPIE 10664, Autonomous Air and Ground Sensing Systems for Agricultural Optimization and Phenotyping III, 1066401 (30 July 2018); doi: 10.1117/12.2502380

SPIE Event: SPIE Commercial + Scientific Sensing and Imaging, 2018, Orlando, FL, United States 


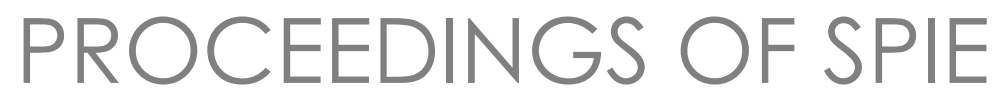

\title{
Autonomous Air and Ground Sensing Systems for Agricultural Optimization and Phenotyping III
}

\author{
J. Alex Thomasson \\ Mac McKee \\ Robert J. Moorhead \\ Editors
}

16-17 April 2018

Orlando, Florida, United States

Sponsored by

SPIE

Cosponsored by

Monsanto Company (United States)

Published by

SPIE 
The papers in this volume were part of the technical conference cited on the cover and title page. Papers were selected and subject to review by the editors and conference program committee. Some conference presentations may not be available for publication. Additional papers and presentation recordings may be available online in the SPIE Digital Library at SPIEDigitalLibrary.org.

The papers reflect the work and thoughts of the authors and are published herein as submitted. The publisher is not responsible for the validity of the information or for any outcomes resulting from reliance thereon.

Please use the following format to cite material from these proceedings:

Author(s), "Title of Paper," in Autonomous Air and Ground Sensing Systems for Agricultural Optimization and Phenotyping III, edited by J. Alex Thomasson, Mac McKee, Robert J. Moorhead, Proceedings of SPIE Vol. 10664 (SPIE, Bellingham, WA, 2018) Seven-digit Article CID Number.

ISSN: 0277-786X

ISSN: 1996-756X (electronic)

ISBN: 9781510618398

ISBN: 9781510618404 (electronic)

Published by

SPIE

P.O. Box 10, Bellingham, Washington 98227-0010 USA

Telephone +1 3606763290 (Pacific Time) · Fax +1 3606471445

SPIE.org

Copyright (C) 2018, Society of Photo-Optical Instrumentation Engineers.

Copying of material in this book for internal or personal use, or for the internal or personal use of specific clients, beyond the fair use provisions granted by the U.S. Copyright Law is authorized by SPIE subject to payment of copying fees. The Transactional Reporting Service base fee for this volume is $\$ 18.00$ per article (or portion thereof), which should be paid directly to the Copyright Clearance Center (CCC), 222 Rosewood Drive, Danvers, MA 01923. Payment may also be made electronically through CCC Online at copyright.com. Other copying for republication, resale, advertising or promotion, or any form of systematic or multiple reproduction of any material in this book is prohibited except with permission in writing from the publisher. The CCC fee code is 0277$786 \mathrm{X} / 18 / \$ 18.00$.

Printed in the United States of America.

Publication of record for individual papers is online in the SPIE Digital Library.

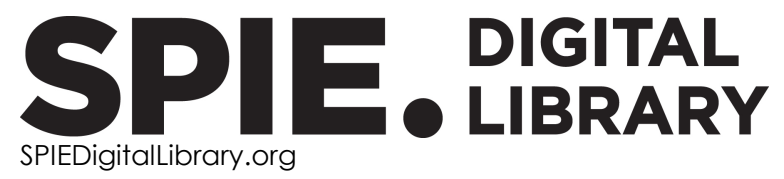

Paper Numbering: Proceedings of SPIE follow an e-First publication model. A unique citation identifier (CID) number is assigned to each article at the time of publication. Utilization of CIDs allows articles to be fully citable as soon as they are published online, and connects the same identifier to all online and print versions of the publication. SPIE uses a seven-digit CID article numbering system structured as follows:

- The first five digits correspond to the SPIE volume number.

- The last two digits indicate publication order within the volume using a Base 36 numbering system employing both numerals and letters. These two-number sets start with $00,01,02,03,04$, 05, 06, 07, 08, 09, OA, OB ... 0Z, followed by 10-1Z, 20-2Z, etc. The CID Number appears on each page of the manuscript. 


\title{
Contents
}

\author{
vii Authors \\ xi Conference Committee
}

SESSION 1 COLLECTING RELIABLE IMAGE DATA WITH UAVS

1066402 Implications of sensor inconsistencies and remote sensing error in the use of small unmanned aerial systems for generation of information products for agricultural management (Invited Paper) [10664-1]

1066403 Ground-truthing of UAV-based remote sensing data of citrus plants [10664-2]

1066404 Quality assessment of radiometric calibration of UAV image mosaics [10664-3]

1066405 Correction of in-flight luminosity variations in multispectral UAS images, using a luminosity sensor and camera pair for improved biomass estimation in precision agriculture [10664-4]

1066406 An initial exploration of vicarious and in-scene calibration techniques for small unmanned aircraft systems [10664-5]

1066407 Behavior of vegetation/soil indices in shaded and sunlit pixels and evaluation of different shadow compensation methods using UAV high-resolution imagery over vineyards [10664-6]

\section{SESSION 2 PROXIMAL AND REMOTE SENSING FOR PHENOTYPING}

1066409 Detection of canola flowering using proximal and aerial remote sensing techniques (Invited Paper) [10664-8]

10664 OA Vinobot and vinoculer: from real to simulated platforms [10664-34]

10664 OB Phenotyping of sorghum panicles using unmanned aerial system (UAS) data [10664-9]

10664 OD Calibrated plant height estimates with structure from motion from fixed-wing UAV images [10664-11] 
$10664 \mathrm{OE}$ Inter-comparison of thermal measurements using ground-based sensors, UAV thermal cameras, and eddy covariance radiometers [10664-12]

$10664 \mathrm{OF}$ A detailed study on accuracy of uncooled thermal cameras by exploring the data collection workflow [10664-13]

$10664 \mathrm{OH} \quad$ A low-cost method for collecting hyperspectral measurements from a small unmanned aircraft system [10664-15]

10664 Ol Hyperspectral detection of methane stressed vegetation (Best Paper Award) [10664-16]

SESSION 4 DETECTING YIELD, DISEASE, AND WATER STRESS FROM UAVS

10664 OK Multispectral remote sensing for yield estimation using high-resolution imagery from an unmanned aerial vehicle [10664-18]

10664 OL Disease defection and mitigation in a cotton crop with UAV remote sensing [10664-19]

10664 OM An unmanned aerial system for the detection of crops with undergraduate project-based learning (Invited Paper) [10664-35]

10664 ON Experimental approach to detect water stress in ornamental plants using sUAS-imagery [10664-20]

\section{SESSION $5 \quad$ ANALYTICS FOR UAV-BASED CROP MANAGEMENT}

1066400 Machine learning techniques for the assessment of citrus plant health using UAV-based digital images [10664-21]

$106640 Q \quad$ Evaluation of multispectral unmanned aerial systems for irrigation management [10664-23]

SESSION 6 INNOVATIVE UAV APPLICATIONS

10664 OR UAV videos to extend research to producers [10664-25]

10664 OS A comparison of manned and unmanned aerial Lidar systems in the context of sustainable forest management [10664-26]

10664 OT Spatial analysis of multispectral and thermal imagery from multiple platforms [10664-27]

10664 OU Evaluating the capabilities of Sentinel-2 and Tetracam RGB+3 for multi-temporal detection of thrips on capsicum [10664-28] 
$10664 \mathrm{OW} \quad$ Using hyperspectral sensors for crop vegetation status monitoring in precision agriculture [10664-32]

10664 OX MoniSCAN: software for multispectral monitoring of the crops vegetation status [10664-33] 
Proc. of SPIE Vol. 10664 1066401-6

Downloaded From: https://www.spiedigitallibrary.org/conference-proceedings-of-spie on 26 Apr 2023 Terms of Use: https://www.spiedigitallibrary.org/terms-of-use 


\title{
Authors
}

Numbers in the index correspond to the last two digits of the seven-digit citation identifier (CID) article numbering system used in Proceedings of SPIE. The first five digits reflect the volume number. Base 36 numbering is employed for the last two digits and indicates the order of articles within the volume. Numbers start with 00, 01, 02, 03, 04, 05, 06, 07, 08, 09, OA, OB...0Z, followed by 10-1Z, 20-2Z, etc.

\author{
Aboutalebi, Mahyar, 02, 07, 0K \\ Accettura, Margot, 01 \\ Allen, Niel, OK \\ Altenhofen, Jon, $0 Q$ \\ Anderson, Andreas, OF \\ Ansari, Mehdi, 03 \\ Bagnall, Cody, 04, OD \\ Bauch, Timothy D., 06, 01 \\ Bhandari, Subodh, 03, 00 \\ Boer, Attila Laszlo, OW, OX \\ Brown, Jack, 09 \\ Capurro, Maria Cristina, $0 Q$ \\ Chaichi, Mohammad R., 03 \\ Chang, Anjin, OB, OD \\ Chávez, José L., $0 Q$ \\ Chen, YangQuan, OF \\ Collatz, Wesley, OE \\ Collett, Ryan, OL \\ Connal, Ryan J., 06 \\ Coopmans, Calvin, 07, OE \\ Cope, Dale A., OD \\ Craine, Wilson, 09 \\ Cristea, Luciana, OW, OX \\ Davis, James B., 09 \\ de Castro, Ana I., ON \\ DeSouza, Guilherme N., OA \\ Do, Dat, 03, 00 \\ Domenzain, Luis Mario, 05 \\ Elarab, Manal, $\mathrm{OE}$ \\ Espinas, Antonio, 03 \\ Fallet, Clément, 05 \\ Faroux, Romain, 05 \\ Fritschi, Felix B., OA \\ Gadsden, A. D., OM \\ Gadsden, S. A., OM \\ Gauns, Arvind, OU \\ Gilliot, Jean-Marc, 05 \\ Green, Robert L., 03 \\ Hale, D. Stuart, os \\ Hamidisepehr, Ali, $\mathrm{OH}$ \\ Han, Xiongzhe, OD \\ Hartzell, Ryan A., 06 \\ Henry, W. Brien, OR \\ Horne, David W., OD \\ Hulbert, Scott H., 09 \\ Jung, Jinha, OB, OD \\ Kha, Kevin, 06 \\ Khot, Lav R., 09 \\ Knappen, Jackson S., 06
}

Kustas, William, 02, 07, 0E

Landivar, J., OB

Luculescu, Marius Cristian, OW, OX

Maeda, M., OB

Maja, Joe Mari, ON

Malambo, L., OD

Mallia, Joe, 01

Mamaghani, Baabak G., 06

Marcellus, Evan D., 06

Marzougui, Afef, 09

Masih, Ashish, $O Q$

McClelland, Michael P., II, OS

McKee, Lynn, OE

McKee, Mac, 02, 07, 0E

Michelin, Joël, 05

Mohite, Jayantrao, OU

Moorhead, Robert, OR

Morgan, Cristine, OT

Nassar, Ayman, 02

Neely, Haly, OT

Nichols, Robert L., OL

Nieto, Hector, 07, OE

Niu, Haoyu, OF

Owen, Jim, ON

Pappula, Srinivasu, OU

Parry, Chistopher, OE

Peña, Jose M., ON

Pham, Frank, 03, 00

Pugh, N. Ace, OD

Raheja, Amar, 03, 00

Raqueño, Nina G., 06, 01

Robbins, James, ON

Rooney, William L., OD

Rouze, Gregory, OT

Salvaggio, Carl, 06, 0I

Sama, Michael P., $\mathrm{OH}$

Sankaran, Sindhuja, 09

Sasaki, Geoffrey V., 06

Shafiekhani, Ali, OA

Sherman, Tristan, 03

Sima, Chao, 04

Thomasson, J. Alex, 04, OD, OL

Torres-Rua, Alfonso F., 02, 07, OE, OK

Twarakavi, Navin, OU

van Aardt, Jan, OS

Viers, Joshua, OF

Wang, Tianyi, OL

Wang, Xiwei, OL

Wasson, Louis, OR 
Wilkerson, S. A., OM

Williams, John J., OR

Wolf, Joseph, 03

Yang, Chenghai, 04, OL, OT

Yeom, J., OB

Zamfira, Sorin Constantin, OW, OX

Zhang, Chongyuan, 09

Zhang, Huihui, $O Q$

Zhao, Tiebiao, OF

Proc. of SPIE Vol. 10664 1066401-8

Downloaded From: https://www.spiedigitallibrary.org/conference-proceedings-of-spie on 26 Apr 2023 Terms of Use: https://www.spiedigitallibrary.org/terms-of-use 


\title{
Conference Committee
}

\author{
Symposium Chair
}

Robert Fiete, Harris Corporation (United States)

Symposium Co-chair

Jay Kumler, JENOPTIK Optical Systems, LLC (United States)

Conference Chairs

J. Alex Thomasson, Texas A\&M University (United States)

Mac McKee, Utah State University (United States)

Robert J. Moorhead, Mississippi State University (United States)

Conference Program Committee

Atanu Basu, Ayata (United States)

Christoph Baver, KWS SAAT AG (Germany)

Subodh Bhandari, California State Polytechnic Univ., Pomona (United States)

Andrew N. French, Agricultural Research Service (United States)

Yufeng Ge, University of Nebraska-Lincoln (United States)

Cheryl McCarthy, University of Southern Queensland (Australia)

Seth C. Murray, Texas A\&M University (United States)

Haly Neely, Texas A\&M University (United States)

Boyan Peshlov, Climate Corporation (United States)

Carl Salvaggio, Rochester Institute of Technology (United States)

Michael Sama, University of Kentucky (United States)

Sindhuja Sankaran, Washington State University (United States)

Ajay Sharda, Kansas State University (United States)

Yeyin Shi, University of Nebraska-Lincoln (United States)

Session Chairs

1 Collecting Reliable Image Data with UAVs

J. Alex Thomasson, Texas A\&M University (United States)

2 Proximal and Remote Sensing for Phenotyping

Robert J. Moorhead, Mississippi State University (United States)

3 Thermal and Hyperspectral Imaging from UAVs

Mac McKee, Utah State University (United States) 
4 Detecting Yield, Disease, and Water Stress from UAVs

Robert J. Moorhead, Mississippi State University (United States)

5 Analytics for UAV-based Crop Management

Mac McKee, Utah State University (United States)

6 Innovative UAV Applications

J. Alex Thomasson, Texas A\&M University (United States) 